\title{
Politics Of Law Human Rights Protection In Indonesia
}

\section{Andi Pradikta Alvat ${ }^{1}$}

Abstract. This study aims to know how political development of legal protection of human rights in Indonesia and political objectives of the legal protection of human rights itself. The research method using normative juridical approach. Specification of the research is descriptive. Provide an overview and critical analysis and conclusions of the research object. Source data using secondary data sources through books and legislation. The data collection method through the study of literature. Analysis of data using qualitative approach. The results showed that the political development of the legal protection of human rights has undergone discourse tight since the formulation of the Constitution and found basic juridical-constitutional is ideal since the reform era with the birth of Chapter $X A$ in the constitution on human rights, born Law of Human Rights, and the formation of the court of HAM. The purpose of a political human rights protection law contains three dimensions, namely the dimensions of philosophical, sociological dimension and juridical dimension.

Keywords: Protection Of Human Rights; Political Law; State Law.

\section{Introduction}

Indonesia is a country of law as defined in Article 1 (3) Constitution NRI 1945, is simply a state of law is a state that the basic organization of the country based on law and not on power, the state of law, the law will be laid down as a basic foundation in the state governance which serves as a means to organize the life of society, as the foundation of the validity of policies, actions and decisions taken, as a means to prevent and resolve conflicts and as an effort to protect human rights.

According Joniearto, the rule of law implies that the state enforcement action authorities should be based on the law is not based on power and will of the governing sheer whose purpose is to limit the power of rulers, and protect the public interest, namely the protection of the human rights community members from arbitrary action ruler. $^{2}$ It could be said that the life or the core rather than the rule of law is the protection of human rights. Protection of human rights is fundamental to the rule of law for all things which is the principle of the state law would basically boils down to the street to protect human rights, if human rights are guaranteed and protected it will then create a conducive atmosphere in society, nation and state that would be optimal to encourage the achievement of the ideals of the country.

Indonesia as a country that adheres to the rule of law since its inception has been revealed in the opening, torso, and explanation of the 1945 Constitution which explicitly states the recognition and protection of human rights. Even the constitution

\footnotetext{
${ }^{1}$ Student of Master of Law, Faculty of Law, Sultan Agung Islamic University, Semarang, Email: andialvatpradikta@gmail.com

2 Joeniarto, 1968, Negara Hukum, Yogyakarta: Yayasan Penerbit Gajah Mada, p 53
} 
itself is proof that Indonesia is a country of law in view of the constitution itself is a logical consequence of the acceptance of the rule of law. ${ }^{3}$

The rule of law can not be separated from the concept of the protection of human rights, legal state without the protection of human rights, the state of the law would lose its meaning and legitimacy as a state of law, while human rights protection in the absence of the container country of law, then created tyranny and personal egoism. Protection of human rights is how the state established a policy to prevent and tackle the infringement of human rights either intentionally or omission. ${ }^{4}$ Protection of human rights involves two things namely the means of prevention and also a means of repression.

Basing on the above background, the formulation of the issues raised were: How the political dynamics of human rights protection law in Indonesia? What political purpose of human rights protection law in Indonesia?

\section{Research Methods}

The method used is used in this paper is a normative juridical research method. A method of scientific research approaches to find the truth based on the logic of the normative legal scholarship obtained from secondary legal sources such as books and legislation. Normative juridical research method aims to know how the political dynamics of the legal protection of human rights in Indonesia. Specification of the research is descriptive. Provide an overview and critical analysis and conclusions of the research object. Source data using secondary data sources through books and legislation. The data collection method using literature study. Methods of data analysis using a qualitative approach.

\section{Discussion}

\subsection{Political Dynamics of Legal Protection of Human Rights in Indonesia}

Determination of what law policy to be applied for the protection of human rights is then referred to as a legal political protection of human rights. Before going any further would be preferable if the authors explain in advance what the politics of law and human rights, so that the construction can then provide a more comprehensive understanding to the reader. Legal politics is defined by Satjipto Rahardjo as an activity to choose and the means to be used to achieve a social goal with certain laws in the community whose scope includes the answers to several fundamental questions, namely: 1 . What goals are to be achieved through the existing system, 2 . How is the best way to achieve that goal, 3 . When is the time and how the law has been changed, 4. Can a standard and established pattern be formulated to assist in formulating the process of selecting goals and ways to achieve these goals properly.

\footnotetext{
${ }^{3}$ Moh Mahfud MD, 2010, Membangun Politik Hukum, Menegakkan Konstitusi, Jakarta: Rajawali Press, p. 41

${ }^{4}$ Suparman Marzuki, 2011, Tragedi Politik Ham, Yogyakarta: Pustaka Pelajar, p. 18
} 
Mahfud MD defines legal politics as a "Legal Policy" or official policy line on law that will be enforced either by making new laws or by changing old laws in order to achieve the goals of the country. Thus legal politics is related to choices about law to be enacted and law to be repealed, all of which are intended to achieve the goals of the state as mandated in the opening of the 1945 Constitution.

From the two definitions of legal politics proposed by the two legal experts above, if a red thread can be drawn about the meaning, definition and understanding of legal politics, the author defines legal politics as an official policy established by the state regarding law, both with legal reform or legal repeal. the purpose of which is to make law as a means to achieve the objectives of the law itself, namely aspects of legal certainty, usefulness and justice as well as to achieve the goals of the state as mandated in the opening of the 1945 Constitution of Republic of Indonesia paragraph IV.

Thus the politics of law can be understood as an attempt to reconstruct the law either by legal reform or repeal of the law to achieve legal in all aspire (ius constituendum) in order to realize the purpose of the law in particular and the purpose of the state in general, therefore, the legal politics should dynamic always follow the development of social dynamics, economic, and cultural communities.

After knowing the sense, the definition and understanding of the political law will further explain the authors understanding of human rights. According to Act No. 39 of 1999 concerning Human Rights, human rights are defined as a set of rights attached to nature and human existence as a creature of God Almighty and is a gift of HIS which must be respected, upheld and protected by the state, law, government, and everyone for the respect and protection of human dignity.

According to the resolution of the general assembly of the United Nations number 217 A (III) of 10 December 1948, human rights are a set of individual rights consisting of:

- The same rights in the context of independence since birth

- The right of freedom to earn a living and safety

- The right to be free from bondage act

- Right to freedom of religion and ideology

- The right to obtain political asylum

- The right to marry and continue the descent

Definition of human rights can also be found in the MPR-R 1 No. XVII / MPR / 1998 on human rights in item 1 letter $D$ point 1 which defines human rights as a right as a gift of God Almighty inherent in human beings, is natural, universal, and timeless associated with human dignity.

According to Soetandyo Wignjosoebroto, human rights are rights inherently inherent in every creature that is born with a human biological form, which provides moral certainty and has freedom from all forms of actions and treatments that prevent human beings from living properly as human beings who are glorified by humans. God, and therefore it is not possible to be transferred or even taken away to bear the authority of the state though, unless it is reduced on the basis of the agreement of the rights holders through truly representative legislative processes for the sake of upholding the human rights of others in public life. 
Meaning or definition of the above it is understood that human rights are basic rights that are naturally possessed by humans since birth as a gift from god if not complied with or deprived of the human being can not be called as human beings. So then this human rights should be protected through the regulatory process or policy law which became known as the politics of human rights protection laws.

Politics of human rights protection law is a legal policy that is implemented either by making, renewing, replacing or revoking laws and regulations relating to the protection of human rights for the realization of full protection of human rights. If viewed from the historical point of view the birth of the political law of human rights protection has lasted for centuries manifested in the history of the liberation of slaves, protection of women's rights, to the struggle of the lower classes to escape the trappings of oppression from the authoritarianism of the rulers in the royal era in the era of the kingdom then.

In the dynamics of the modern state, political issues of human rights protection laws not only concept but an inseparable part of the overall concept of the legal state. That means that human rights are an integral part of the principles of the modern state. Mahfud MD argues that there are three principles of the state of life that are closely interwoven with one another which is born of the Enlightenment political philosophy are:

- Democracy

- State of Law

- Protection of Human Rights. ${ }^{5}$

So it can be understood that the politics of law protecting human rights is a logical consequence that is closely interrelated with one another with the principles of democracy and the rule of law. The politics of protecting human rights will always be related to the principles of the rule of law and democracy so that the dynamics of the rule of law and democracy will influence how the policy or politics of the law protect human rights.

Indeed, the struggle over how human rights in the state took place at the time of drafting the 1945 constitution, at that time there was a debate between Sukarno and Soepomo on the one hand and M. Hatta and M. Yamin on the other hand, regarding the urgency of whether citizens' human rights need regulated and stated in the 1945 Constitution.

Soerkano and Soepomo said that the human rights of citizens do not need to be regulated in the constitution. In Soekarno's and Soepomo's view, the constitution is "Philosopische gronslag" which is not based on liberalism and capitalism. In Soekarno's opinion the guarantee of the protection of the citizens' rights came from the French revolution which was thick with the values of liberalism and individualism which triggered the creation of imperialism and war between fellow human beings. Soekarno wanted a state based on the principle of kinship and mutual cooperation and therefore the citizens' human rights did not need to be guaranteed in the constitution.

\footnotetext{
${ }^{5}$ Moh Mahfud MD, 1999, Pergulatan Politik dan Hukum di Indonesia, Yogyakarta: Gama Media, p. 157158
} 
Whereas in the view of M. Hatta and M. Yamin, it is necessary to include the rights of citizens in the constitution as a form of protection of human rights while avoiding the state from the authoritarianism of the authorities. The debate in the BPUPKI session between Sukarno and Soepomo against M. Hattta and M. Yamin later became an important milestone in the political discourse on the protection of human rights in Indonesia after the birth of a compromise to include the rights of citizens included in the constitution although limited, not only limited in the sense regulated further by law but also conceptually limited in terms of the rights of citizens not human rights. In this position the state has a role as a regulator of the rights of citizens, not a guardian of human rights.

Political discourse and legal debate on the protection of human rights has not ended, the discourse on protecting human rights reappeared in the 1957-1959 constituent assembly recorded in the Constituent Minutes of the National Commission on Human Rights, according to Adnan Buyung Nasution this discussion was the most ideal, clear and good statement regarding human rights awareness among the people of Indonesia. In this discourse, human rights began to get a place not only about the rights of citizens, universal human rights began to get attention, but unfortunately the Constituent Assembly was dissolved by Sukarno based on Presidential Decree July 5, 1959.

Then entering the new order of protection of human rights does not get a meaningful place in government policies that tend to use repressive and authoritarian means. During the New Order era, Indonesia was spurring economic development with the slogan that all efforts to promote and protect human rights were considered as obstacles to development. Therefore, the government tends to be defensive and that is reflected in the legal products in that period which are generally restrictive towards human rights.

In the new order of human rights is at the nadir given the lack of government attention to the protection of human rights otherwise the government would be repressive and authoritarianism that resulted in the fulfillment of human rights protection be achieved, with character of government new order regime are regarded as periodization of the leadership of Indonesia's worst relating to the Protection and fulfillment of human rights, even at the end of his reign era rampant human rights violations such as abductions and missing and a mysterious shooting.

Entering new era of political reform the legal protection of human rights began to gain serious attention to the marked enactment of Act No. 39 of 1999 on Human Rights as a follow up of the MPR Decree No. XVII of 1998 containing cargo charter of human rights, and the mandate to the government and agencies countries to advance the protection of human rights. Politics of human rights protection law then guaranteed in the Constitution through the amendment set forth in Chapter XA on Human Rights, hereinafter also established a human rights court through Act No. 26 of 2000. Following a second amendment to the Constitution by the birth of the chapter on human rights XA then guaranteed protection of human rights in Indonesia constitutionally protected as before the amendment just rights of citizens does not cover the whole human. 


\subsection{Political Interest Legal Protection of Human Rights in Indonesia}

Speaking about the political purpose of human rights protection law it can not be released rather than political objectives of the law itself in general. Politics of human rights protection law gives the sense that the protection of human rights should get a place in the formulation of legal policy to provide juridical guarantees constitutional, in my opinion there are three perspectives on the political importance of the legal protection of human rights in Indonesia.

- In Philosophical

The political policy of protecting human rights philosophically aims to improve and accommodate the dynamics of human rights development towards a more appropriate direction in order to support the realization of the ideals and objectives of the state as mandated by the opening of the 1945 Constitution of the Republic of Indonesia Paragraph IV. Philosophically, the law on human rights protection is in the context of encouraging the realization of the goals of the state.

- Sociology

In political sociology legal protection of human rights aims to guarantee and protect human rights in order to create order, harmony and the establishment of social cohesion in society, sociologically can be understood that the purpose of legal politics human rights protection is in order to demonstrate the existence of oneself in the international world, because without the recognition and protection of human rights would undoubtedly an isolated country in the international arena stage.

- By juridical

Legally legal political human rights protection is a mandate of the Constitution of us who embraced the doctrine of state law as provided in Article 1 (3) Constitution of NRI 1945 which explained that the Indonesian state is a state of law, as a constitutional state based on Pancasila, especially humanitarian precepts of fair and civilized state should fulfill, guaranteeing and protecting human rights as legal policies set out in the legislation. By state law doctrine, the state is obligated to repair, renewal and promotion of policies for the protection of human rights of all things for the sake of the upright and the fulfillment of the protection of human rights in the struggle for the life of society, nation and state.

\section{Closing}

\subsection{Conclusion}

- The development of the legal politics of human rights protection starts from the discussion of the tough draft of the Constitution between our Founding Fathers namely Sukarno and Soepomo on one side and M. Hatta and M. Yamin. Soekarno and Soepomo assumed that the regulation of citizens' rights into the constitution was a legacy of liberalism and individualism as inheritance from the French revolution which had caused imperialism and fellow human wars, on the one hand M. Hattta and M. Yamin denied the understanding of Soekarno and Soepomo. In 
their view, both M. Hatta and M. Yamin, the regulation and guarantee of citizens' rights in the constitution is a form of state attention to protect its citizens so it does not need to be seen as a manifestation of liberalism and individualism. Then finally a compromise was reached to include the protection of citizens 'rights in the constitution even though limited human rights of citizens have not touched universal human rights, then in the new order of human rights and even citizens' human rights were at the nadir, the government tended to be repressive and authoritarian under the pretext of the development process, the protection of human rights will only hamper development, then the protection of human rights will be constitutionally protected in the reform era with the birth of several legal instruments for the protection of human rights namely Law Number 39 of 1999 concerning Human Rights, the second amendment The Constitution with the birth of chapter XA on Human Rights, and the birth of the Law on Human Rights Courts.

- The purpose of the legal politics of protecting human rights contains three reasons namely philosophical, sociological and juridical. Philosophically, the law on the protection of human rights is aimed at creating reinforcement of the principle of protection of human rights in order to support the realization of the ideals and objectives of the state as enshrined in the opening of the Constitution paragraph IV. Sociologically the aim of the political law is the protection of human rights in order to create a harmonious, orderly and conducive atmosphere in social cohesion between people in social, national and state life as well as a means to show their existence on the international stage. Juridical the purpose of the political law is the protection of human rights is as a manifestation of the principle of the rule of law considering that Indonesia is a state of law.

\subsection{Suggestion}

Human rights are the basic principles of a constitutional state must be met may not be so. Thus, of the protection of human rights should always be considered and secured at the level of philosophical, juridical, and sociological human rights that every human being can be assured.

\section{References}

[1] Adnan Buyung Nasution, 1995, Apirasi Pemerintahan Konsitusional di Indonesia, Studi : Sosio-legal atas konstituante 1956-1959, Jakarta: Gramedia Pustaka Utama

[2] Bagir manan 2006, Perkembangan Pemikiran dan Pengaturan HAM di Indonesia, Bandung: Alumni

[3] Joeniarto, 1968, Negara Hukum, Yogyakarta: Yayasan Penerbit Gadjah Mada

[4] Moh Mahfud MD, 2011, Politik Hukum di Indonesia, Jakarta: Rajawali Press

[5] Moh Mahfud MD, 2010, Membangun Politik Hukum, Menegakkan Konstitusi, Jakarta: Rajawali Press

[6] Moh Mahfud MD, 1999, Pergulatan Politik dan Hukum di Indonesia, Yogyakarta: Gama Media 
[7] Satjipto Rahardjo, 1991, Ilmu Hukum, Bandung: Citra Aditya Bakti

[8] Satya Arinanto, 2003, Transisi Politik di Indonesia, Jakarta: Center for the Study of State Constitutional Law Faculty of Law, University of Indonesia

[9] Soetandyo Wignyosoebroto 2002, Hukum : Paradigma Metode dan Masalah, Jakarta: Elsam and Huma

[10] Suparman Marzuki, 2011, Tragedi Politik HAM, Yogyakarta: Pustaka Pelajar

[11] Todung Mulya Lubis, 1993, In Search of Human Rights: Legal-Political dilemmas of Indonesia's order from 1966 to 1990, Jakarta: Gramedia Pustaka Utama 